\title{
Erratum to: Wound Healing Properties of Collagen from the Bone of Two Marine Fishes
}

\author{
N. S. Sampath Kumar $\cdot$ R. A. Nazeer
}

Published online: 10 June 2012

(C) Springer Science+Business Media, LLC 2012

Erratum to: Int J Pept Res Ther

DOI 10.1007/s10989-012-9291-2

The original version of this article unfortunately contained a mistake. It contained an incorrect author name who has not contributed to this work. The correct author names are mentioned in this erratum.

The online version of the original article can be found under doi:10.1007/s10989-012-9291-2. 